\title{
Neuroprotection of geniposide against hydrogen peroxide induced PC12 cells injury: involvement of PI3 kinase signal pathway
}

\author{
Jian-hui LIU' ${ }^{1, *}$, Fei YIN ${ }^{1}$, Li-xia GUO ${ }^{1}$, Xiao-hong DENG ${ }^{1}$, Yin-he $\mathrm{HU}^{2}$ \\ ${ }^{1}$ Research Center of Medicinal Chemistry and Chemical Biology, Chongqing Technology and Business University, Chongqing 400067, China; ${ }^{2}$ Research \\ Center of Brain Functional Genome, East China Normal University, Shanghai 200062, China
}

\begin{abstract}
Aim: Oxidative stress plays a critical role in the pathogenic cascade leading to neuronal degeneration in AD. Consequently, the induction of endogenous antioxidative proteins by antioxidants seems to be a very reasonable strategy for delaying the disease's progression. In previous work, we identified the neurotrophic and neuroprotective effects of geniposide, which result from the activation of glucagon-like peptide 1 receptor (GLP-1R). In this study, we explore the role of PI3 kinase signaling pathway in the neuroprotection of geniposide in PC12 cells.

Methods: Cell viability was determined by MTT assay. Apoptosis was detected by Hoechst and PI double staining. The protein expression of Bcl-2 and phosphorylation of Akt308, Akt473, GSK-3 $\beta$, and PDK1 was measured by Western blot.

Results: Geniposide induced the expression of the antiapoptotic protein Bcl-2, which inhibited apoptosis in PC12 cells induced by $\mathrm{H}_{2} \mathrm{O}_{2}$, and this effect could be inhibited by preincubation with LY294002, a selective inhibitor of PI3K. Furthermore, geniposide enhanced the phosphorylation of Akt308, Akt473, GSK-3 $\beta$ and PDK1 under conditions of oxidative stress. Conclusion: These results demonstrate that the PI3K signaling pathway is involved in the neuroprotection of geniposide in PC12 cells against the oxidative damage induced by $\mathrm{H}_{2} \mathrm{O}_{2}$ in PC12 cells.
\end{abstract}

Keywords: geniposide; glucagon-like peptide 1 receptor; PI3K; GSK-3 $\beta$; PDK1

Acta Pharmacologica Sinica (2009) 30: 159-165; doi: 10.1038/aps.2008.25; published online 19th January 2009

\section{Introduction}

Glucagon-like peptide-1 (GLP-1) is an endogenous peptide that is secreted from the gut in response to the ingestion of food ${ }^{[1]}$. It has potent effects on glucose-dependent insulin secretion and insulin gene expression via its action on the pancreas following its binding at the G-proteincoupled GLP-1 receptor $(\mathrm{GLP}-1 \mathrm{R})^{[2]}$. There is also evidence to indicate that type II diabetes, or at least impaired glucose tolerance, is associated with impaired recognition of GLP-1, independent of age ${ }^{[3]}$. In activating its receptor, GLP-1 shows diverse physiological actions that include insulinotropic, cardiovascular and neurotrophic effects. The ability to modulate these physiological parameters may be proved beneficial in a variety of diseases prevalent in aging, including stroke and Alzheimer's disease $(\mathrm{AD})^{[4-7]}$. Unfortunately, the biological activity of GLP-1 is inhibited through $\mathrm{N}$-terminal

\footnotetext{
* Corresponding to Dr Jian-hui LIU.

E-mail jhliu@ctbu.edu.cn

Received 2008-10-31 Accepted 2008-12-16
}

degradation by the common endogenous aminopeptidase enzyme dipeptidyl peptidase IV (DPP IV), which not only inactivates GLP-1 but may turn it into an antagonist for the GLP-1R receptor ${ }^{[8]}$. This represents a potential challenge to therapeutic efforts directed at enhancing GLP-1 activity in vivo. Because numerous reports document GLP-1R expression in both the rodent and human brains, the development of natural products as lead compounds to activate GLP-1R in the brain may be useful in central nervous system degenerative disorders such as stroke and Alzheimer's disease ${ }^{[3,6,9]}$.

In our previous work, we demonstrated that geniposide, isolated from Gardenia jasminoides Ellis, activated the glucagon-like peptide 1 receptor (GLP-1R) in a manner similar to GLP-1, and showed neurotrophic properties that induced the neuronal differentiation of PC12 cells by stimulating cAMP production. Furthermore, we found that geniposide could prevent oxidative damage induced by $\mathrm{H}_{2} \mathrm{O}_{2}$ in $\mathrm{PC} 12$ cells via the MAP kinase signaling pathway ${ }^{[10,11]}$. Activation of GLP-1R on the cell membrane of pancreatic $\beta$ cells has been shown to modulate mitosis, growth and differentiation, and much is known about the cellular signaling pathway 
triggered by GLP-1 binding to its pancreatic receptor ${ }^{[12-14]}$. However, little has been confirmed in neuronal cells. In this study, we explore the signaling pathway of geniposide in activating GLP-1R in PC12 cells.

$\mathrm{Bcl}-2$ is a gene family involved in the suppression of apoptosis in response to a wide range of cellular insults ${ }^{[15]}$. Many papers have suggested a link between $\mathrm{Bcl}-2$ and oxidative damage/antioxidant protection ${ }^{[16,17]}$. Here we report that geniposide, a selective agonist for GLP-1R, induces the expression of $\mathrm{Bcl}-2$, which in turn decreases oxidative damage in PC12 cells. This effect is mediated by the phosphorylation of Akt, PDK1 and GSK. Furthermore, this effect is inhibited partly by LY294002, a selective inhibitor of phosphatidylinositol 3-kinase (PI3K). Together, these data suggests that $\mathrm{PI} 3 \mathrm{~K}$ is involved in the neuroprotection of geniposide in PC12 cells challenged by $\mathrm{H}_{2} \mathrm{O}_{2}$.

\section{Materials and methods}

\section{Materials}

Materials were obtained from the following sources: PC12 cells were obtained from the cell bank of type culture collection of Chinese Academy of Sciences; LY294002, antiphospho-Akt308, -Akt473, -PDK1, -GSK-3 $\beta$, anti-Bcl-2, antiAkt, anti-HO-1, anti- $\beta$-actin, anti-GADPH and horseradish peroxidase-conjugated goat anti-rabbit (mouse) antibodies were purchased from Cell Signaling Technology; fetal bovine serum, horse serum, penicillin/streptomycin, and Dulbecco's modified Eagle's medium (DMEM) were purchased from HyClone; ECL advance was purchased from Amersham; polyvinylidene difluoride membranes were purchased from Millipore; and geniposide was purchased from Sichuan Dicotyledonous Bio-tech Co, Ltd (purity is over 99.5\%, UR20060421). All other reagents were purchased from Amersco, except where indicated.

\section{Cell culture and drug treatment}

PC12 cells were maintained in DMEM containing 5\% fetal bovine serum, $10 \%$ horse serum, $100 \mathrm{U} / \mathrm{mL}$ penicillin, and $100 \mathrm{mg} / \mathrm{mL}$ streptomycin sulfate at $37^{\circ} \mathrm{C}$ with $5 \% \mathrm{CO}_{2}$. For experiments involving geniposide and PC12 cells, the cells were plated in 6-well culture dishes at $5 \times 10^{5}$ cells $/ \mathrm{mL}$. The cells were preincubated for $30 \mathrm{~min}$ with or without LY294002 before the addition of $\mathrm{H}_{2} \mathrm{O}_{2}$. After treatment with $50 \mu \mathrm{mol} / \mathrm{L}$ geniposide for $2 \mathrm{~h}$, cells were incubated with 100 $\mu \mathrm{mol} / \mathrm{L} \mathrm{H}_{2} \mathrm{O}_{2}$ for the indicated time. LY294002, a specific inhibitor of PI3K, was diluted in dimethyl sulfoxide to a final concentration in the medium of $10 \mu \mathrm{mol} / \mathrm{L}$.

\section{Determination of cell viability}

Cells were seeded in 6-well plates at a density of $5 \times 10^{5}$ cells $/ \mathrm{mL}$. In the cytotoxic studies, PC12 cells were treated with geniposide and $\mathrm{H}_{2} \mathrm{O}_{2}$ at the indicated concentration for $24 \mathrm{~h}$ at $37^{\circ} \mathrm{C}$. To assess the cytoprotection of geniposide, PC12 cells were treated with geniposide for $2 \mathrm{~h}$ before $\mathrm{H}_{2} \mathrm{O}_{2}$ was added. Finally, the cells' viability was determined by the 3-(4,5-dimethylthiazol-2-yl)-2,5-diphenyltetrazolium bromide (MTT) colorimetric assay. The cells were incubated for $2 \mathrm{~h}$ at $37^{\circ} \mathrm{C}$ with MTT $(0.5 \mathrm{mg} / \mathrm{mL}$ final concentration) and then dissolved in fresh complete medium, in which the metabolically active cells reduced the dye to purple formazan. The formazan crystals were dissolved in DMSO, and the absorbance was measured on a BMG microplate reader (BMG Technologies), using a reference wavelength of 630 $\mathrm{nm}$ and a test wavelength of $570 \mathrm{~nm}$.

\section{Hoechst and PI double staining}

In the morphological studies, the cells were grown on slides and treated with geniposide and $\mathrm{H}_{2} \mathrm{O}_{2}$ as described above. After a wash with PBS, the cells were stained with Hoechst $33258(1 \mu \mathrm{g} / \mathrm{mL})$ for 7-10 $\mathrm{min}$ at room temperature, and then stained with $5 \mu \mathrm{g} / \mathrm{mL}$ PI (propidium iodide) for 1-2 min. After a final wash in PBS, the cells were photographed under UV light with a microscope (Nikon, Japan).

\section{SDS-PAGE and Western blot analysis}

Western blot analysis was performed on $20 \mu \mathrm{g}$ of protein from each cell lysate. The proteins were electroblotted onto a polyvinylidene difluoride (PVDF) membrane after being fractionated by SDS-PAGE. The membranes were blocked with $20 \mathrm{mmol} / \mathrm{L}$ Tris, $150 \mathrm{mmol} / \mathrm{L} \mathrm{NaCl}, \mathrm{pH} 7.5$, and 5\% nonfat dry milk at room temperature for $1 \mathrm{~h}$. Primary and second antibodies were diluted in blocking solution and incubated with the membranes for the indicated times as described previously ${ }^{[18]}$. Excess antibody was washed off with a $20 \mathrm{mmol} / \mathrm{L}$ TBST $(20 \mathrm{mmol} / \mathrm{L}$ Tris, $150 \mathrm{mmol} / \mathrm{L}$ $\mathrm{NaCl}, \mathrm{pH} 7.5$, and $0.1 \%$ Tween 20 ) solution before incubation in ECL advance. The membrane was subsequently exposed to photographic film. Western blot results were quantified by analyzing the X-ray films using software from Quantity One.

\section{Statistical analysis}

When necessary, data are expressed as mean $\pm \mathrm{SD}$, and variance analysis was carried out using Origin 7.5. Values of $P<0.05$ were considered statistically significant. 

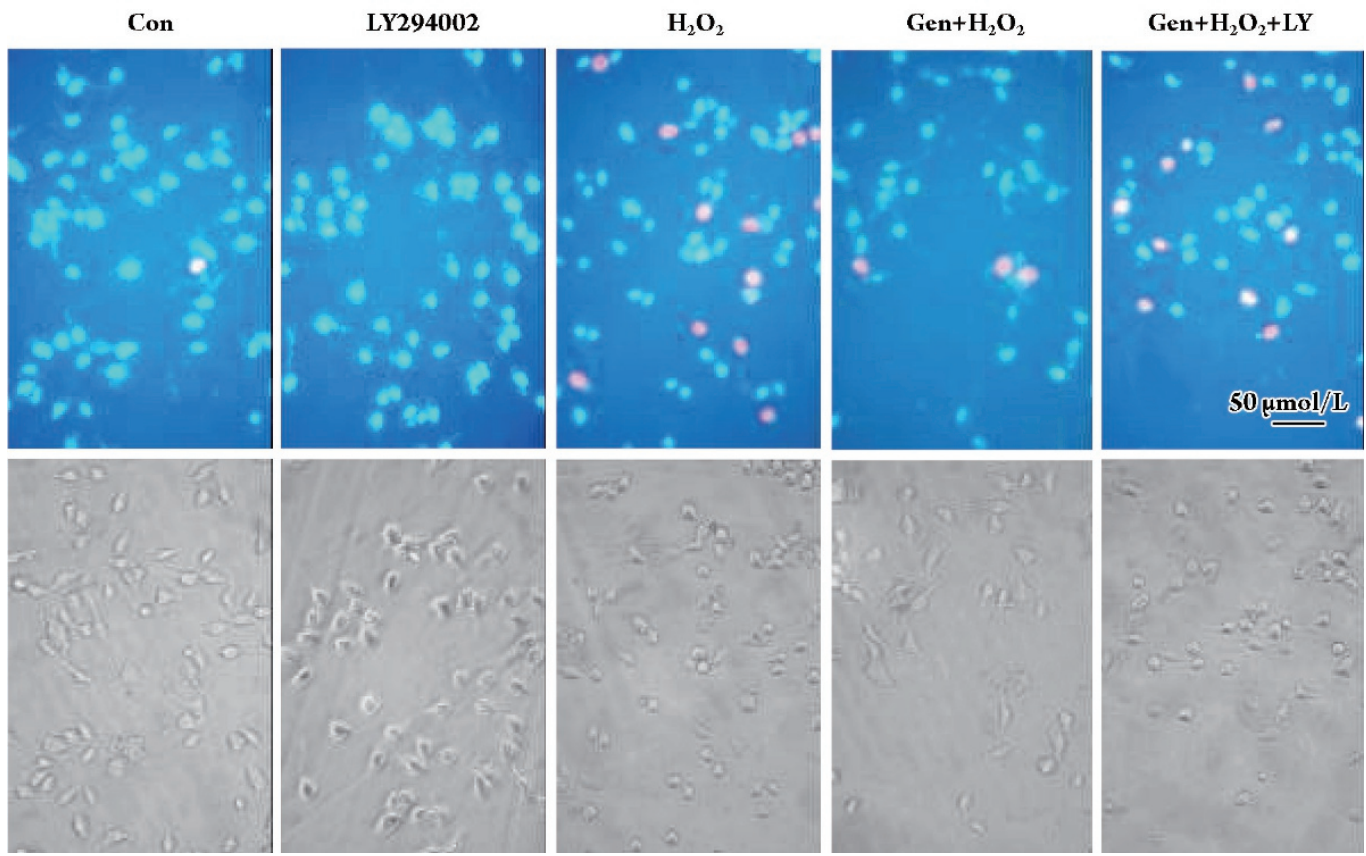

Figure 1. Geniposide (Gen) inhibits the apoptosis of $\mathrm{PC} 12$ cells induced by $\mathrm{H}_{2} \mathrm{O}_{2}$. To analyze the role of geniposide in preventing the apoptosis of $\mathrm{PC} 12$ cells induced by $\mathrm{H}_{2} \mathrm{O}_{2}, \mathrm{PC} 12$ cells were plated in 6-well culture dishes at $5 \times 10^{5}$ cells $/ \mathrm{mL}$ and preincubated for 30 min in the presence or absence of LY294002 $(10 \mu \mathrm{mol} / \mathrm{L})$ before the addition of geniposide and $\mathrm{H}_{2} \mathrm{O}_{2}$. After treatment with $50 \mu$ mol/L geniposide for $2 \mathrm{~h}$, cells were treated with $100 \mu \mathrm{mol} / \mathrm{L} \mathrm{H}_{2} \mathrm{O}_{2}$ for 2-4 h, and the treated cells were double stained with PI/Hoechst 33258 and the positive cells were counted. The results shown are from a representative experiment, which was repeated at least three times. (Scale bar is $50 \mu \mathrm{mol} / \mathrm{L}$ )

\section{Results}

\section{Geniposide decreases apoptosis in PC12 cells induced by $\mathrm{H}_{2} \mathrm{O}_{2}$}

In previous work, we identified that geniposide activated the GLP-1 receptor and increased PC12 cells' viability in a dose-dependent manner ${ }^{[11]}$. With PI/Hoechst 33258 double staining, we found that preincubation with geniposide could inhibit apoptosis in PC12 cells induced by $\mathrm{H}_{2} \mathrm{O}_{2}$, with the percentage of apoptotic cells decreasing from $42.7 \% \pm 7.6 \%$ to $15.9 \% \pm 6.3 \%$ (Figure 1). We also observed that the neuroprotective effect of geniposide was attenuated by LY294002, a selective inhibitor of PI3K. Using the MTT method, we determined the influence of geniposide on the viability of PC12 cells treated with $\mathrm{H}_{2} \mathrm{O}_{2}$ in the presence or absence of LY294002. The results showed that geniposide increased the viability of the cells from $51.7 \% \pm 11.3 \%$ to $77.9 \% \pm 9.3 \%$. Furthermore, this effect could be inhibited by preincubation with LY294002 (Figure 2). In total, these results suggest that the PI3K pathway is involved in the neuroprotection of geniposide in PC12 cells.

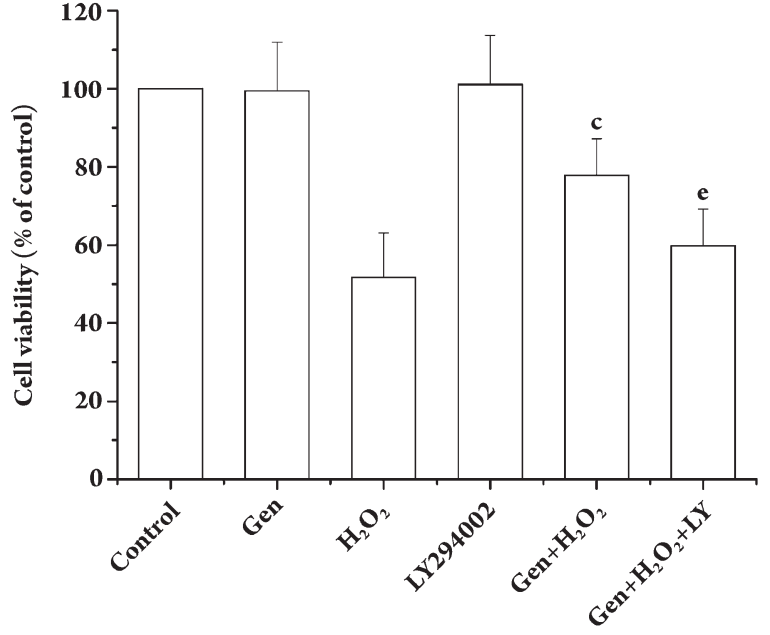

Figure 2. Effect of LY294002 on the neuroprotection of geniposide(Gen) against oxidative damaged PC12 cells. PC12 cells were maintained for $12-16 \mathrm{~h}$ in normal media supplied with $10 \% \mathrm{HS}$ and 5\% FBS and then stimulated with vehicle $\left(\mathrm{Me}_{2} \mathrm{SO}\right)$ or $\mathrm{Gen} 50 \mu \mathrm{mol} / \mathrm{L}$ for 2-4 h. After that, the cells were pretreated with $10 \mu \mathrm{mol} / \mathrm{L}$ LY294002 for 15-30 min and submitted to $100 \mu \mathrm{mol} / \mathrm{L} \mathrm{H}_{2} \mathrm{O}_{2}$ as indicated for 2-4 h, and then analyzed by the MTT method. All data are shown as mean \pm SD from three independent repeats. ${ }^{c} P<0.01$ vs $\mathrm{H}_{2} \mathrm{O}_{2}$ treated group. ${ }^{e} \mathrm{P}<0.05$ vs the group treated with $\mathrm{Gen}+\mathrm{H}_{2} \mathrm{O}_{2}$. 
Geniposide increases the expression of antiapoptotic Bcl-2 proteins

The bcl-2 proteins are a family of proteins involved in responding to apoptotic signals ${ }^{[19]}$. A lot of evidences have demonstrated that $\mathrm{Bcl}-2$ plays a critical role in preventing oxidative damage to cells induced by highly reactive hydroxyl radicals $(. \mathrm{OH})$ from $\mathrm{H}_{2} \mathrm{O}_{2}{ }^{[20]}$. An excess of $\mathrm{Bcl}-2$ in cells will tend to make them more resistant to oxidative stress. In studying the factors that could lead to the prosurvival effect of geniposide, we investigated its influence on the expression of $\mathrm{Bcl}-2$, a main regulator of cell apoptosis. The results demonstrated that, treatment of the PC12 cells with $50 \mu \mathrm{mol} / \mathrm{L}$ geniposide increased the expression of bcl- 2 by about 1.57 fold relative to the control. Furthermore, in the presence of $\mathrm{H}_{2} \mathrm{O}_{2}$, the over-expression of bcl-2 in the PC12 cells exposed to geniposide increased to 2.21 -fold that of the control. However, preincubation with LY294002 attenuated the expression of $\mathrm{Bcl}-2$ induced by geniposide (Figure 3 ).
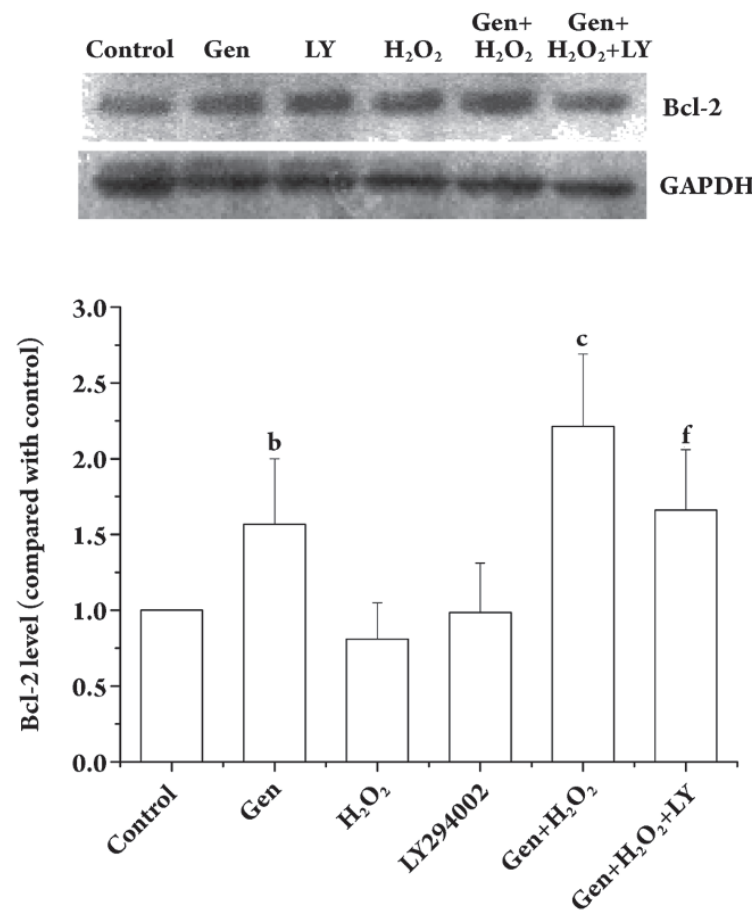

Figure 3. Geniposide regulates the expression of $\mathrm{Bcl}-2$ to antagonize the oxidative damage induced by $\mathrm{H}_{2} \mathrm{O}_{2}$ in PC12 cells. After the PC12 cells were treated with the agents listed in the Materials and methods section, equal proteins were separated with SDS-PAGE, and the Bcl-2 proteins were probed by Western blot. The experiments were repeated at least three times, and the results are shown as mean \pm SD. ${ }^{b} P<0.05$, ${ }^{\mathrm{c}} \mathrm{P}<0.01$ vs the control group. ${ }^{\mathrm{f}} \mathrm{P}<0.01$ vs the group treated with $\mathrm{Gen}+\mathrm{H}_{2} \mathrm{O}_{2}$. LY: LY294002.
Neuroprotective action of geniposide is mediated by the activation of a PI3K-dependent signaling pathway in PC12 cells

Activation of the PI3K pathway is known to elicit a survival signal against multiple proapoptotic insults ${ }^{[21]}$. To determine whether the activation of the PI3K pathway is involved in the downstream signaling pathway responsible for the up-regulation of $\mathrm{Bcl}-2$ expression and for protection from $\mathrm{H}_{2} \mathrm{O}_{2}$ induced apoptosis, we examined the effects of LY294002, a selective inhibitor of PI3K, on the phosphorylation of Akt, a downstream substrate of PI3K activity. The results from Western blot experiments showed that treatment with $50 \mu \mathrm{mol} / \mathrm{L}$ geniposide for $1 \mathrm{~h}$ increased the phosphorylation of Akt 308 by about 3.72-fold in PC12 cells, and that after the addition of $\mathrm{H}_{2} \mathrm{O}_{2}$ and incubation for one additional hour, the level of Akt308 phosphorylation increased to 4.71fold that of the control cells. We also found that treatment with geniposide alone had no significant influence on the phosphorylation of Akt473, another kinase downstream of PI3K, but in the presence of $\mathrm{H}_{2} \mathrm{O}_{2}$, geniposide did increase phosphorylation by about 1.92 -fold. This activity was also inhibited by preincubation with LY294002. However, the level of unphosphorylated Akt enzyme remained unchanged in $\mathrm{PC} 12$ cells in the presence of $\mathrm{H}_{2} \mathrm{O}_{2}$ (Figure 4).

Moreover, we also explored the effects of geniposide on the activity of upstream and downstream kinases, such as PDK1 and GSK-3 $\beta$. We found that oxidative stress decreased the level of phosphorylated GSK-3 $\beta$ in PC12 cells, but that geniposide enhanced the phosphorylation of PDK1 and GSK-3 $\beta$ in the presence or absence of $\mathrm{H}_{2} \mathrm{O}_{2}$. These effects were attenuated by the PI3K inhibitor, LY294002. The levels of phosphorylated PDK1 and GSK-3 $\beta$ decreased from 4.59fold to 2.91-fold and from 2.93-fold to 1.45-fold, respectively, after a 30-min preincubation with $10 \mu \mathrm{mol} / \mathrm{L}$ LY294002 (Figure 5).

\section{Discussion}

Oxidative stress contributes, at least in part, to the pathogenic cascade leading to neuronal degeneration in $\mathrm{AD}^{[22,23]}$. The induction of endogenous antioxidative proteins by antioxidants seems to be a very reasonable strategy for delaying the disease's progression ${ }^{[24]}$. In previous work, we reported that geniposide, a selective agonist for the GLP-1 receptor, showed neurotrophic properties, such as inducing neuronal differentiation of PC12 cells and preventing oxidative damage via the MAP kinase pathway in PC12 cells ${ }^{[10,11]}$. However, the mechanisms by which geniposide activates GLP-1R and imparts its neuroprotective effects are not fully under- 

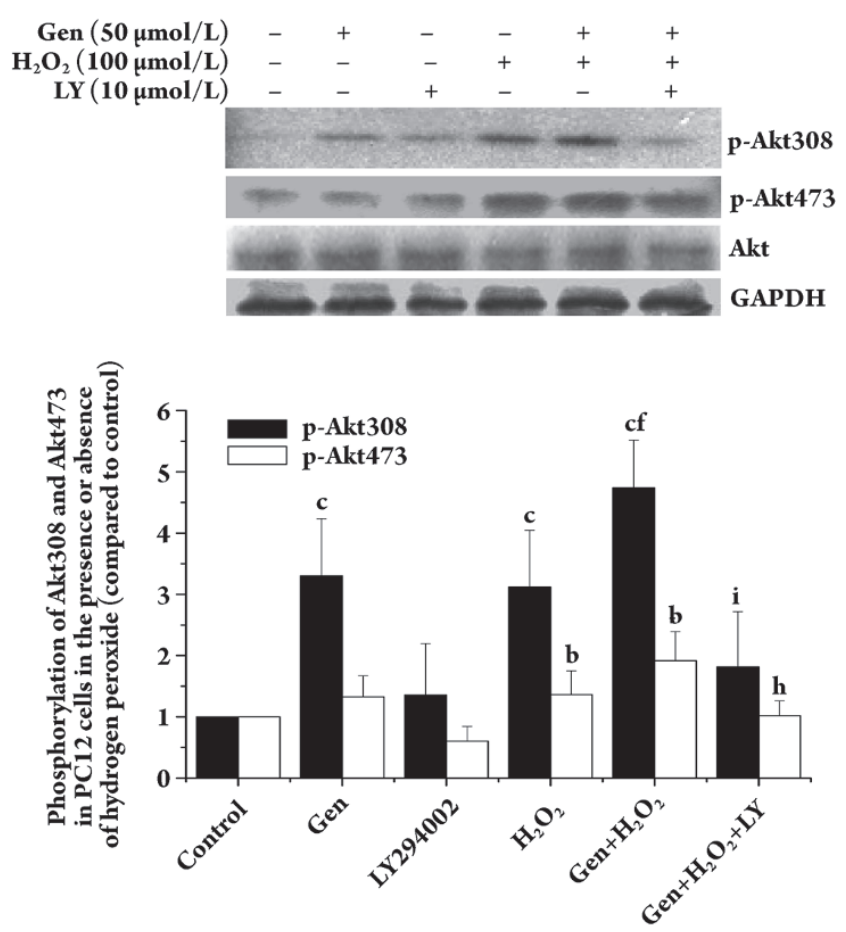

Figure 4. The effect of LY294002, a PI3K inhibitor, on the phosphorylation of Akt308 and Akt473 in PC12 cells treated with $\mathrm{H}_{2} \mathrm{O}_{2}$. PC12 cells were plated into 6-well culture dishes at $1 \times 10^{6}$ cells $/ \mathrm{mL}$ and maintained for $12-16 \mathrm{~h}$ in normal media supplied with $10 \% \mathrm{HS}$ and $5 \% \mathrm{FBS}$, and then treated with $50 \mu \mathrm{mol} / \mathrm{L}$ geniposide for 2-4 h. After that, the cells were pretreated with $10 \mu \mathrm{mol} / \mathrm{L}$ LY294002 for $15-30 \mathrm{~min}$ and submitted to $100 \mu \mathrm{mol} / \mathrm{L} \mathrm{H}_{2} \mathrm{O}_{2}$ for about $1 \mathrm{~h}$. After the cells were washed three times with PBS, the cell lysate was collected to assay the phosphorylated Akt308 and Akt473. The results shown are from a representative experiment, which was repeated at least three times. The data are shown as mean $\pm \mathrm{SD}$ from three independent experiments. ${ }^{b} P<0.05,{ }^{c} P<0.01 v s$ the control; ${ }^{\mathrm{f}} P<0.01 v s$ the group of treatment with $\mathrm{H}_{2} \mathrm{O}_{2}$ alone; ${ }^{\mathrm{h}} \mathrm{P}<0.05,{ }^{\mathrm{i}} \mathrm{P}<0.01$ vs the group treated with Gen $+\mathrm{H}_{2} \mathrm{O}_{2}$. Gen: geniposide; LY: LY294002.

stood. In this study, we proposed that the neuroprotection associated with geniposide was caused by an antiapoptotic effect related to the drug-induced over-expression of Bcl-2. The over-expression of $\mathrm{Bcl}-2$ resulting from the activation of PI3K, a major signaling pathway implicated in supporting neuronal survival. We first investigated the effect of geniposide on cellular apoptosis and viability. Preincubation with geniposide significantly decreased apoptosis and increased the viability of $\mathrm{PC} 12$ cells challenged with $\mathrm{H}_{2} \mathrm{O}_{2}$. Additionally, we also identified that this effect involved the modulation of geniposide on the phosphorylation of Akt, PDK1, and GSK-3 $\beta$.

The data increasingly support the notion that the GLP-1R signal is mediated by the phosphatidyl-inositol-
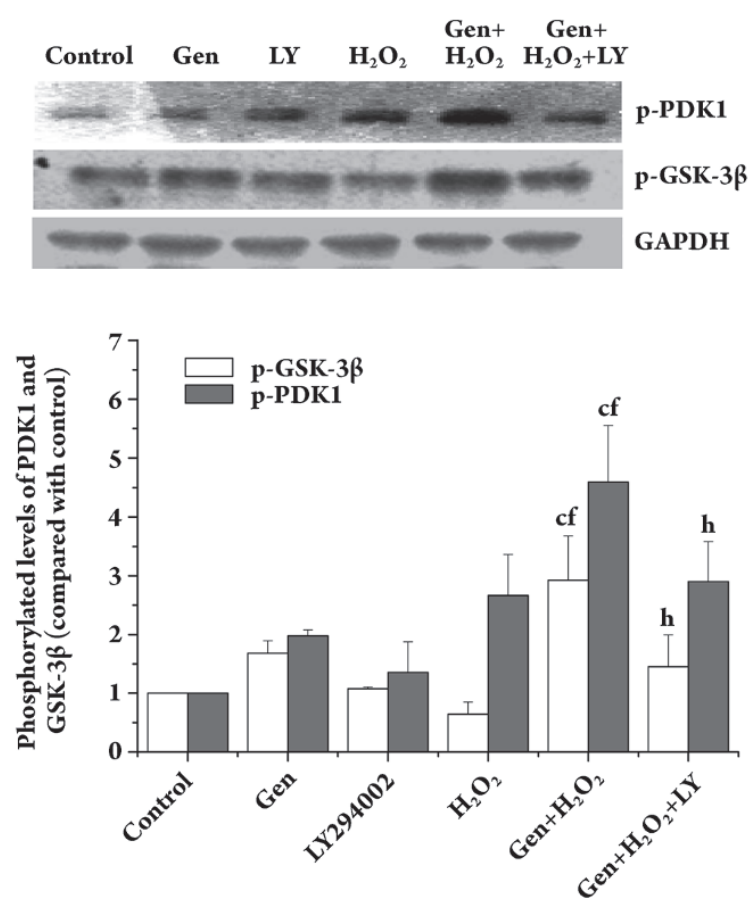

Figure 5. Geniposide regulates the phosphorylation of PDK1 and GSK- $3 \beta$ in PC12 cells treated with $\mathrm{H}_{2} \mathrm{O}_{2}$. PC12 cells were plated into 6-well culture dishes at $1 \times 10^{6}$ cells $/ \mathrm{mL}$ and maintained for $12-16 \mathrm{~h}$ in normal media supplied with $10 \%$ HS and 5\% FBS, and then treated with $50 \mu \mathrm{mol} / \mathrm{L}$ geniposide for $2-4 \mathrm{~h}$. Then the cells were pretreated with $10 \mu \mathrm{mol} / \mathrm{L} \mathrm{LY294002} \mathrm{for} 15-30 \mathrm{~min}$ and submitted to 100 $\mu \mathrm{mol} / \mathrm{L} \mathrm{H}_{2} \mathrm{O}_{2}$ for about $1 \mathrm{~h}$ The cells were then washed with PBS three times, and the cell lysate was collected to assay the phosphorylated PDK1 and GSK-3 $\beta$. The results shown are one from a representative one from at least three repeating experiments. The data are shown as mean \pm SD from three independent experiments. ${ }^{c} P<0.01 v s$ the control group. ${ }^{\mathrm{f}} \mathrm{P}<0.01$ vs the group treated with $\mathrm{H}_{2} \mathrm{O}_{2}$ alone; ${ }^{\mathrm{h}} \mathrm{P}<0.05$ vs the group treated with $\mathrm{Gen}+\mathrm{H}_{2} \mathrm{O}_{2}$. Gen: geniposide; LY: LY294002.

3-kinase, cAMP/protein kinase $\mathrm{A}$, and $\mathrm{Ca}^{2+}$-CamKII $a$ pathways $^{[21,25,26]}$. To explore the signal pathway by which geniposide prevents PC12 cells from oxidative damage, we used LY294002 to investigate whether geniposide activates the PI3K pathway. It has been shown that PI3K is regulated primarily by one of its downstream targets-Akt ${ }^{[27]}$. Akt has a direct effect on the apoptosis pathway, by regulating the expression of anti-apoptotic proteins such as $\mathrm{Bcl}-2^{[28]}$. Our results demonstrate that geniposide could induce the expression of the endogenous antiapoptotic protein Bcl-2, which protects against oxidative damage in PC12 cells, and that this neuroprotective effect of geniposide is attenuated by preincubation with the PI3K inhibitor, LY294002. Additionally, we investigated the effect of geniposide on the phosphorylation of Akt and the kinases upstream and downstream of Akt (for example, PDK1, and GSK-3 $\beta$ ). We showed that 
geniposide induced the phosphorylation of Akt308, PDK1, and GSK- $3 \beta$, and enhanced the phosphorylation of Akt308, Akt473, GSK-3 $\beta$, and PDK1 under oxidative stress. These results strongly suggest that the PI3K pathway is involved in neuroprotection of geniposide in PC12 cells.

There is growing evidence that GSK-3 $\beta$ is involved in the pathogenesis of central nervous system diseases. GSK-3 $\beta$ is an enzyme that was initially identified as a regulator of glycogen metabolism, but it also has broader functions ${ }^{[29]}$. Following the PI3K/Akt pathway, we investigated whether geniposide had an influence on GSK-3 $\beta$ phospho-regulation and whether this effect was involved with PI3K by using LY294002. We are the first to demonstrate that geniposide strongly increases the phosphorylation of GSK-3 $\beta$ in the presence of $\mathrm{H}_{2} \mathrm{O}_{2}$, and that this increase is partly abolished by LY294002. Together these data suggest a probable mechanism by which geniposide protects against cell death.

3-Phosphoinositide-dependent protein kinase 1 (PDK1) was originally identified as the activator of the cell survival kinase Akt/PKB ${ }^{[30,31]}$. Subsequently, PDK1 has been shown to be a more versatile kinase. It is involved in a variety of cell functions, including protein synthesis, cell survival, glucose metabolism, and cell adhesion and migration ${ }^{[32,33]}$. In this study, we found that geniposide enhanced the phosphorylation of PDK1 in the presence of $\mathrm{H}_{2} \mathrm{O}_{2}$, and that this effect was inhibited by LY294002, suggesting that PDK1 was also involved in neuroprotection of geniposide in PC12 cells.

At present, the increase in the phosphorylation of Akt, PDK1 and GSK-3 $\beta$ induced by geniposide in $\mathrm{H}_{2} \mathrm{O}_{2}$ challenged cells and inhibition of PI3K, by LY294002, leading to a decrease in the neuroprotection mediated by geniposide, suggest that the PI3K/Akt pathway and GSK- $3 \beta$ could be involved in the mechanism by which geniposide protects PC12 cells from $\mathrm{H}_{2} \mathrm{O}_{2}$-induced cell death. Strikingly, geniposide did not influence Akt phosphorylation in untreated cells but did increase the phosphorylation of PDK1 and GSK-3 $\beta$ in $\mathrm{H}_{2} \mathrm{O}_{2}$-treated PC12 cells, indicating that geniposide is not a direct activator of these pathways but acts as a facilitator of their activation. Although further work is needed to understand the precise mechanism of the neuroprotection provided by geniposide, the present study provides evidence that the PI3K cascade may play an important role in geniposide-induced neuroprotection from oxidative stress, and we are the first to delineate the signaling pathway for the GLP-1 receptor in PC12 cells.

\section{Abbreviations}

GLP-1R, glucagon-like peptide 1 receptor; DPP IV, dipeptidyl peptidase IV ; PI3K, phosphoinositide 3-kinase; GSK-3 $\beta$, glycogen synthase kinase-3beta; PDK1, phosphoinositide-dependent protein kinase 1; MAPK, mitogen-activated protein kinase; $\mathrm{AD}$, Alzheimer's disease; PD, Parkinson's disease; PI, propidium iodide; PBS, phosphate buffer solution; MTT, 3-(4, 5-dimethylthiazol-2-yl)-2, 5-diphenyltetrazolium bromide.

\section{Acknowledgements}

This work was supported by grants from the National Natural Science Foundation of China (30600813, 30701020), the Program for New Century of Excellent Talents in University (NCET-07-0913), and the Chongqing Science \& Technology Commission (CSTC, 2007AA5029), and partly by grants from the Ministry of Science and Technology of China (“973 project”, 2003CB716601)

\section{Author contribution}

Jian-hui LIU and Fei YIN designed research; Jian-hui LIU, Fei YIN, Li-xia GUO, and Xiao-hong DENG performed research; Jian-hui LIU and Fei YIN analyzed data; Jian-hui LIU and Yin-he HU wrote the paper.

\section{References}

1 Ahren B. Glucagon-like peptide-1 (GLP-1): a gut hormone of potential interest in the treatment of diabetes. Bioessays 1998; 20: 642-51.

2 Brubaker PL, Drucker DJ. Minireview: Glucagon-like peptides regulate cell proliferation and apoptosis in the pancreas, gut, and central nervous system. Endocrinology 2004; 145: 2653-9.

3 During MJ, Cao L, Zuzga DS, Francis JS, Fitzsimons HL, Jiao X, et al. Glucagon-like peptide-1 receptor is involved in learning and neuroprotection. Nat Med 2003; 9: 1173-9.

4 Biswas SC, Buteau J, Greene LA. Glucagon-like peptide-1 (GLP-1) diminishes neuronal degeneration and death caused by ngf deprivation by suppressing bim induction. Neurochem Res 2008; 33: 1845-51.

5 Gilman CP, Perry T, Furukawa K, Grieg NH, Egan JM, Mattson MP. Glucagon-like peptide 1 modulates calcium responses to glutamate and membrane depolarization in hippocampal neurons. J Neurochem 2003; 87: 1137-44.

6 Kakei M, Yada T, Nakagawa A, Nakabayashi H. Glucagon-like peptide- 1 evokes action potentials and increases cytosolic $\mathrm{Ca}^{2+}$ in rat nodose ganglion neurons. Auton Neurosci 2002; 102: 39-44.

7 Biswas SC, Buteau J, Greene LA. Glucagon-like peptide-1 (GLP-1) diminishes neuronal degeneration and death caused by NGF deprivation by suppressing Bim induction. Neurochem Res 2008; 33: $1845-51$.

8 Holst JJ. The physiology of glucagon-like peptide 1. Physiol Rev 2007; 87: 1409-39.

9 Kauth T, Metz J. Immunohistochemical localization of glucagonlike peptide 1. Use of poly-and monoclonal antibodies. Histo- 
chemistry 1987; 86: 509-15.

10 Liu J, Zheng X, Yin F, Hu Y, Guo L, Deng X, et al. Neurotrophic property of geniposide for inducing the neuronal differentiation of PC12 cells. Int J Dev Neurosci 2006; 24: 419-24.

11 Liu J, Yin F, Zheng X, Jing J, Hu Y. Geniposide, a novel agonist for GLP-1 receptor, prevents PC12 cells from oxidative damage via MAP kinase pathway. Neurochem Int 2007; 51: 361-9.

12 Acitores A, Gonzalez N, Sancho V, Valverde I, VillanuevaPenacarrillo ML. Cell signalling of glucagon-like peptide-1 action in rat skeletal muscle. J Endocrinol 2004; 180: 389-98.

13 Gonzalez N, Acitores A, Sancho V, Valverde I, VillanuevaPenacarrillo ML. Effect of GLP-1 on glucose transport and its cell signalling in human myocytes. Regul Pept 2005; 126: 203-11.

14 Sancho V, Nuche B, Arnes L, Cancelas J, Gonzalez N, Diaz-Miguel $\mathrm{M}$, et al. The action of GLP-1 and exendins upon glucose transport in normal human adipocytes, and on kinase activity as compared to morbidly obese patients. Int J Mol Med 2007; 19: 961-6.

15 Bogdanov MB, Ferrante RJ, Mueller G, Ramos LE, Martinou JC, Beal MF. Oxidative stress is attenuated in mice overexpressing BCL-2. Neurosci Lett 1999; 262: 33-6.

16 Kaufmann JA, Bickford PC, Taglialatela G. Oxidative-stressdependent up-regulation of $\mathrm{Bcl}-2$ expression in the central nervous system of aged Fisher-344 rats. J Neurochem 2001; 76: 1099-108.

17 Maroto R, Perez-Polo JR. BCL-2-related protein expression in apoptosis: oxidative stress versus serum deprivation in PC12 cells. J Neurochem 1997; 69: 514-23.

18 Yang Y, Zhou LB, Liu SQ, Tang JF, Li FY, Li RY, et al. Expression of feeding-related peptide receptors mRNA in GT1-7 cell line and roles of leptin and orexins in control of $\mathrm{GnRH}$ secretion. Acta Pharmacol Sin 2005; 26: 976-81.

19 Kowaltowski AJ, Fenton RG, Fiskum G. Bcl-2 family proteins regulate mitochondrial reactive oxygen production and protect against oxidative stress. Free Radic Biol Med 2004; 37: 1845-53.

20 Longoni B, Boschi E, Demontis GC, Marchiafava PL, Mosca F. Regulation of $\mathrm{Bcl}-2$ protein expression during oxidative stress in neuronal and in endothelial cells. Biochem Biophys Res Commun 1999; 260: 522-6.

21 Hui L, Pei DS, Zhang QG, Guan QH, Zhang GY. The neuroprotection of insulin on ischemic brain injury in rat hippocampus through negative regulation of JNK signaling pathway by PI3K/
Akt activation. Brain Res 2005; 1052: 1-9.

22 Potashkin JA, Meredith GE. The role of oxidative stress in the dysregulation of gene expression and protein metabolism in neurodegenerative disease. Antioxid Redox Signal 2006; 8: 144-51.

23 Albers DS, Beal MF. Mitochondrial dysfunction and oxidative stress in aging and neurodegenerative disease. J Neural Transm Suppl 2000; 59: 133-54.

24 Dubinina EE, Kovrugina SV, Konovalov PV. The factors of oxidative stress in neurodegenerative diseases (vascular dementia, Alzheimer disease). Adv Gerontol 2007; 20: 109-13.

25 Arnes L, Gonzalez N, Tornero-Esteban P, Sancho V, Acitores A, Valverde I, et al. Characteristics of GLP-1 and exendins action upon glucose transport and metabolism in type 2 diabetic rat skeletal muscle. Int J Mol Med 2008; 22: 127-32.

26 Sancho V, Trigo MV, Gonzalez N, Valverde I, Malaisse WJ, Villanueva-Penacarrillo ML. Effects of glucagon-like peptide- 1 and exendins on kinase activity, glucose transport and lipid metabolism in adipocytes from normal and type-2 diabetic rats. J Mol Endocrinol 2005; 35: 27-38.

27 Shang Y, Wu Y, Yao S, Wang X, Feng D, Yang W. Protective effect of erythropoietin against ketamine-induced apoptosis in cultured rat cortical neurons: involvement of PI3K/Akt and GSK-3 beta pathway. Apoptosis 2007; 12: 2187-95.

28 Trisciuoglio D, Iervolino A, Zupi G, Del Bufalo D. Involvement of PI3K and MAPK signaling in bcl-2-induced vascular endothelial growth factor expression in melanoma cells. Mol Biol Cell 2005; 16: 4153-62.

29 Frame S, Cohen P. GSK3 takes centre stage more than 20 years after its discovery. Biochem J 2001; 359: 1-16.

30 Vanhaesebroeck B, Alessi DR. The PI3K-PDK1 connection: more than just a road to PKB. Biochem J 2000; $346 \mathrm{Pt}$ 3: 561-76.

31 Knauf C, Cani PD, Kim DH, Iglesias MA, Chabo C, Waget A, et al. Role of central nervous system glucagon-like peptide-1 receptors in enteric glucose sensing. Diabetes 2008; 57: 2603-12.

32 Fresno Vara JA, Casado E, de Castro J, Cejas P, Belda-Iniesta C, Gonzalez-Baron M. PI3K/Akt signalling pathway and cancer. Cancer Treat Rev 2004; 30: 193-204.

33 Harris TK. PDK1 and PKB/Akt: ideal targets for development of new strategies to structure-based drug design. IUBMB Life 2003; 55: $117-26$ 